University of Nebraska - Lincoln

DigitalCommons@University of Nebraska - Lincoln

Mammalogy Papers: University of Nebraska

State Museum

Museum, University of Nebraska State

1952

\title{
Red-Backed Vole with a Tick Attached Near Eyeball
}

H. L. Gunderson

University of Minnesota

Follow this and additional works at: https://digitalcommons.unl.edu/museummammalogy

Part of the Zoology Commons

Gunderson, H. L., "Red-Backed Vole with a Tick Attached Near Eyeball" (1952). Mammalogy Papers:

University of Nebraska State Museum. 155.

https://digitalcommons.unl.edu/museummammalogy/155

This Article is brought to you for free and open access by the Museum, University of Nebraska State at DigitalCommons@University of Nebraska - Lincoln. It has been accepted for inclusion in Mammalogy Papers: University of Nebraska State Museum by an authorized administrator of DigitalCommons@University of Nebraska Lincoln. 


\section{RED-BACKED VOLE WITH A TICK ATTACHED NEAR EYEBALL}

A red-backed vole (Clethrionomys gapperi), with a tick attached to or just under the inner corner of the eyelid at the canthus, was caught in a live trap on July 11, 1951. This is an unusual place of attachment and it is difficult to understand how the tick could have become attached at a point where it could easily be scratched off by either the forefoot or hind foot of the vole.

The engorged tick was attached in such a manner that close examination and moving of the tick might injure the eye. The eyelids were nearly closed, leaving only a narrow slit through which the eyeball appeared glassy. The hair immediately surrounding the eye had been scratched off. The vole was sluggish. On July 13, the vole was recaptured and the tick had dropped off. The vole seemed more active, but the eye was still slightly milky in appearance. The vole, retrapped again on August 1, appeared normally active, the eye appeared normal and the hair around the eye had regrown. It was evident that the tick depressed the vitality of the vole, yet the vole seemed to completely recover.-HARver L. Gunderson, Museum of Natural History, University of Minnesota, Minneapolis 14, Minn. Received December 8, 1951. 